\title{
Photosynthetic analysis of mid-vein and leaf lamina in high-yield hybrid rice in fields during senescence
}

\author{
Zhiping Gao \\ Nanjing Normal University \\ Minli Xu \\ Nanjing Normal Unoversity \\ Haizi Zhang \\ Nanjing Normal University \\ Guoxiang Chen ( $\nabla 08295 @ n j n u . e d u . c n)$ \\ https://orcid.org/0000-0002-2604-2984
}

\section{Original article}

Keywords: mid-vein, rice, photosynthetic properties, senescence

Posted Date: September 1st, 2020

DOI: https://doi.org/10.21203/rs.3.rs-64011/v1

License: (c) (i) This work is licensed under a Creative Commons Attribution 4.0 International License. Read Full License 


\section{Abstract}

Previous studies on rice (Oryza sativa L.) have shown that different components of the photosynthetic apparatus are not uniformly synthesized or degraded during senescence. However, most of these senescence-related studies focused on leaf lamina, while few have addressed functional aspects on chloroplasts or leaf physiology. Here, we investigated the photosynthetic properties of the mid-vein and leaf lamina in a super high-yield hybrid rice (LYP9) during senescence. We found that assimilation and transpiration decreased more slowly in the mid-vein than in the lamina during senescence, suggesting more sustained photosynthesis in the mid-vein, as well as stronger heat dissipation. Two-dimensional gel electrophoresis revealed that the mid-vein had a higher abundance of proteins involved with energy and lower levels of disease or defense-related proteins, suggesting that photosynthesis and energy metabolism were less affected by senescence in the mid-vein than in leaf lamina. In late senescence stage, the excess energy dissipation in the mid-vein through the xanthophyll cycle had a higher active photosynthetic capacity than in the leaf lamina, and we inferred that the mid-vein and leaf lamina of LYP9 rice aged heterogeneously. Taken together, these results provide new insights into the underlying mechanisms of senescence and associated physiology of the rice mid-vein.

\section{Introduction}

It is generally accepted that carbon isotopic composition of plant material is correlated with $\mathrm{C}_{3}$ or $\mathrm{C}_{4}$ pathways of carbon fixation in photosynthesis (Sage, 2004). The $\mathrm{C}_{4}$ plants are anatomically different from $\mathrm{C}_{3}$ plants and are more efficiently at concentrating carbon dioxide $\left(\mathrm{CO}_{2}\right)$ around a particular enzyme named RuBisCO, which is crucial for photosynthesis. Comparing with $\mathrm{C}_{4}$ plants, $\mathrm{C}_{3}$ plants need more $\mathrm{CO}_{2}$ because of their high light respiration rate and low photosynthesis rate. Although genes required for $\mathrm{C}_{4}$ photosynthesis are also existed in $\mathrm{C}_{3}$ plants, few of them exert related functions in $\mathrm{C}_{3}$ plants. Many $\mathrm{C}_{3}$ plants have several genes needed for $\mathrm{C}_{4}$ photosynthesis, but do not use them in the same way as $\mathrm{C}_{4}$ plants. That is why transforming key genes from $\mathrm{C}_{4}$ plants into $\mathrm{C}_{3}$ plants is intriguing for improving $\mathrm{C}_{3}$ plants photosynthesis and water or nitrogen $(\mathrm{N})$ use efficiency.

The staple food crop rice (Oryza sativa L.) is a typical $\mathrm{C}_{3}$ plant. During rice senescence, rice leaves turn yellow and lose their chlorophyll (Ginsburg et al. 1994). In addition, their chloroplasts undergo ultrastructural changes, resulting in reduced photochemical activity in the leaves and limited photosynthesis efficiency (Harding et al. 1990). Damages to oxygen evolving complex contained photosystem II (PS II) have been reported to occur in many plant species during leaf senescence (Biswal et al. 2012; Deoa and Biswalb 2001; Kusaba et al. 2007; Lu et al. 2001; Clermont., 2004). For example, lower thermoluminescence values (indicative of damage to PSII) were recorded in Arabidopsis thaliana during senescence (Wang et al.2016). Specifically, activities of the whole electron transport chain and reaction center decline acutely at the onset of senescence (Biswal and Prasanna 1978; Prakash et al. 1998). This is coincident with a loss in redox homeostasis in the electron transport chain between PSI and PSII, caused by an increase in the quantity of reduced quinones, representing an energy imbalance. This premise is supported by a decline in the actual quantum yield of PSII in the light adapted state and maximum quantum yield of primary photochemistry in the dark-adapted state of chlorophyll fluorescence. In addition, leaf senescence is also accompanied by a decline in oxygen evolution, stomatal conductance, $\mathrm{CO}_{2}$ fixation and an up-regulation of certain enzymes (Mohapatra et al. 2010). Since leaf senescence has a tremendous negative effect on rice, delaying leaf senescence could be a possible practice to elevate the global yields (Grover 1993; Quirino et al. 2000).

Humbeck et al. (1996) demonstrated that different components of the photosynthetic apparatus were not synthesized or degraded uniformly during senescence. However, senescence-related studies have generally focused on the leaf lamina, and very few focused on chloroplast function, which can also be found in other free heterotrophic plant parts, such as the mid-vein, stem, root, flower and fruit (Aschan and Pfanz 2003; Dima et al. 2006; Kalachanis and Manetas 2010; Pfanz et al. 2002; Shen et al. 2016). In the mid-vein of tobacco (Nicotiana tabacum), celery (Apium graveolens) and A. thaliana (Brown et al. 2010; Hibberd and Quick 2002), the $\mathrm{C}_{4}$ photosynthesis pathway involves $\mathrm{C}_{4}$ acid decarboxylases, whose activity is required for sugar and amino acid metabolism. These studies have revealed aspects of $\mathrm{C}_{3}$ plants that are potentially involved in the preconditioning of $\mathrm{C}_{4}$ pathway evolution. Enzymatic activities that are crucial for $\mathrm{C}_{4}$ photosynthesis have also been identified recently in the mid-vein of rice (Shen et al. 2016; Gao and Shen, 2018), suggesting a potential clue for transgenically providing rice with $C_{4}$ photosynthetic pathways. Hence, photosynthesis in the mid-vein could be an important factor for controlling grain yield. $\mathrm{C}_{4}$-like photosynthesis pathways uncovered in $\mathrm{C}_{3}$ plants were based on the characterization of anatomical structures and $\mathrm{C}_{4}$ related enzymes (Hibberd and Quick, 2002; Hibberd and Covshoff, 2010; Aubry et al., 2011), however, the associated specific photosynthetic machinery of proteome is rarely reported.

Here, we selected the high-yield rice cultivar, Liangyoupei9 (LYP9), which has particularly large mid-veins to study the regulation and coordination of senescence in the mid-vein. We presented a comparative analysis of changes in photosynthetic performance of the leaf lamina and mid-vein during senescence. The assimilation and transpiration rates showed slower decreases in the mid-vein compared to the leaf lamina, suggesting that photosynthesis is likely to occur in the mid-vein. By measuring photosynthetic parameters, photosynthetic pigments and protein levels, we were able to determine whether the rice mid-vein has significant photosynthesis properties during leaf senescence. Heat dissipation and xanthophyll cycle related parameters were also determined, and we found that the heat dissipation performance was stronger in the mid-vein than in the leaf lamina. Protein analysis by two-dimensional gel electrophoresis uncovered a higher abundance of energy-related proteins and lower abundance of disease/defense-related proteins in the mid-vein, which in turn meant that the photosynthetic pathway and energy metabolism of the mid-vein were 
less affected by senescence than in the leaf lamina. Major photosynthetic activity was observed and processes determined in the mid-vein during senescence, providing new insights into the underlying mechanisms of senescence and physiology in the rice mid-vein.

\section{Materials And Methods \\ Plant materials and growth conditions}

The LYP9 rice cultivar was cultivated in experimental fields of Nanjing Normal University. Regular management was performed according to Yu et al. (2012). Sampling was performed in the mornings (09:30 - 10:30 a.m.) on clear days at approximately 7-day intervals from September 11 (premature senescence) to October 10 (near grain harvesting time). A leaf was carefully detached from the petiole with fine forceps and for in vitro experiments, the mid-vein was removed from the leaf, and where necessary any contaminating leaf tissue was stripped removed, following procedures described by Brown et al. (2010). Several plant samples were pooled to obtain sufficient material, frozen in liquid nitrogen and stored at $-80^{\circ} \mathrm{C}$.

\section{Detection of photosynthetic parameters}

Measurements of the assimilation rate (A), transpiration rate (E), internal $\mathrm{CO}_{2}$ concentration (Ci) and water use efficiency (WUE) of the leaf lamina and mid-vein were carried out in the field using a portable photosynthesis system (CIRAS-3, PP-Systems Hitchin, UK). The conditions were: ambient $\mathrm{CO}_{2}$ concentration was $390 \pm 10 \mathrm{mmol} \mathrm{mol}^{-1}$, PAR intensity was at $1,200 \pm 50 \mu \mathrm{mol} \mathrm{m}{ }^{-2} \mathrm{~s}^{-1}$, flow rate was $300 \mathrm{ml} \mathrm{min}^{-1}$, leaf temperature was $25 \pm 1^{\circ} \mathrm{C}$, and relative air humidity was $65-70 \%$ (Zhang et al. 2006). In order to accurately measure the photosynthetic rate of the leaf lamina and mid-vein, a 3 $\mathrm{mm} \times 30 \mathrm{~mm}$ rectangular area was used to cover other tissues and fitted between clips of the CIRAS-3 and the mid-vein or leaf lamina during measurements (Pavlovic et al. 2009). The mid-vein was enclosed in a leaf cuvette and measurements were started in the morning between 09:00 and 10:00 a.m.with 10 repeats for each leaf analyzed, between the period from September 11 (premature senescence) to October 10 (near grain harvesting time).

\section{Measurement of chlorophyll a fluorescence}

Chlorophyll fluorescence parameters in the leaf lamina and mid-vein were estimated simultaneously with a portable fluorometer (Handy PEA, Hansatech, UK) as previously described (Strasser et al. 1995). Samples of leaf lamina and mid-vein still attached to the plants were collected from the midsection of the same leaf during the period from September 11 (premature senescence) to October 10 (near grain harvesting time). To make sure that photon exchange between the instrument and the mid-vein or leaf lamina did not interfere with each other when measuring light intensity, a 3 $\mathrm{mm} \times 15 \mathrm{~mm}$ rectangular area and a non-fluorescing piece of black tape, were used as in Manetas (2004) and Panda et al. (2013). Prior to each measurement, leaf clips for dark adaptation were placed on the leaves for $30 \mathrm{~min}$ and the leaves were then illuminated with continuous red LED light (peak at $650 \mathrm{~nm}$ ) at an excitation irradiance of $3,000 \mu \mathrm{mol} \mathrm{m} \mathrm{m}^{-2} \mathrm{~s}^{-1}$ with a duration of $800 \mathrm{~ms}$. We repeated and recorded these measurements 10 times for each leaf, and the data analysis was performed using the professional PEA Plus and Biolyzer HP3 software (Hansatech, UK). Parameters are described in Table 1.

\section{Measurement of photosynthetic pigments}

For measurements of total chlorophyll (Chl) and carotenoid (Car) concentrations, pigments were extracted with acetone: ethyl alcohol (1:1 v/v) as described by Arnon (1949) and Lichtenthaler (2001). The concentrations of Chl and Car were measured with a spectrophotometer (Genesys 10UV, Thermo, USA) (Lichtenthaler and Wellburn 1983).

The extraction and analysis of xanthophyll by high performance liquid chromatography (HPLC) was performed as previously described (Wright et al. 2011). Under dimmed room lighting, a sample was extracted separately with $85 \%$ acetone and $100 \%$ acetone, before centrifugation for 4 min at $12,000 \mathrm{~g}$ at $4^{\circ} \mathrm{C}$. The supernatant was further cleared by passing through a $0.22 \mu \mathrm{m}$ nylon filter of organic phase (Nylon 66 , Jinteng, China). The xanthophyll was eluted using $100 \%$ of solution A (acetonitrile: methanol, 85:15 v/v) for the first 14.5 min followed by a 2 min linear gradient with $100 \%$ solution B (methanol: ethyl acetate, 68:32 v/v) for an additional $28 \mathrm{~min}$. The xanthophylls were then separated using a non-endcapped Zorbax Elipse ( $250 \mathrm{~mm} \times 4.6 \mathrm{~mm} \mathrm{ID}, \mathrm{XPB}-\mathrm{C} 18,5 \mu \mathrm{m})$ analytical column (Agilent 1100, USA). Pigments were detected by measuring absorbance at $445 \mathrm{~nm}$.

\section{Determination of adenosine triphosphate (ATP) content, and calcium-ATPase ( $\mathrm{Ca}^{2+}$-ATPase) and magnesium-ATPase (Mg ${ }^{2+}$-ATPase) activities}

ATP content was measured using the bioluminescence method described by Zhu et al. (2001) and expressed as $\mu \mathrm{mol}$ (ATP) mg ${ }^{-1}$ (Chl). The assay for $\mathrm{Ca}^{2+}$-ATPase and $\mathrm{Mg}^{2+}$-ATPase activities was performed as described by Vallejos et al. (1983) and Ma et al. (2016).

\section{Two-dimensional electrophoresis (2-DE) and image analysis}

Rice leaves grown for 120 days were collected as material for 2-DE. Protein samples were isolated separately from $1 \mathrm{~g}$ of the leaf lamina and mid-vein using a trichloroacetic acid (TCA)-acetone/phenol extraction method (Wang et al. 2006). Samples were extracted with $10 \%$ (w/v) trichloromethane in acetone and centrifuged at $16,000 \mathrm{~g}$ for $5 \mathrm{~min}$ at $4^{\circ} \mathrm{C}$. The pellet was washed with $0.1 \mathrm{M}$ ammonium acetate and $80 \%$ acetone, incubated at $-20^{\circ} \mathrm{C}$ for $1 \mathrm{~h}$, and centrifuged at $16,000 \mathrm{~g}$ for $20 \mathrm{~min}$ at $4^{\circ} \mathrm{C}$. The pellet was air dried at room temperature. Approximately $0.1 \mathrm{~g}$ pellet was added to $0.6 \mathrm{~mL}$ of a Tris-saturated phenol solution ( $\mathrm{pH} 8.0$ ) and $0.6 \mathrm{~mL}$ of sodium dodecyl sulfate (SDS) buffer ( $30 \%$ sucrose, $2 \%$ SDS, $0.1 \mathrm{M} \mathrm{Tris-HCl}, \mathrm{pH} 8.0,5 \%$ 
mercaptoethanol), incubated for $5 \mathrm{~min}$, and centrifuged at $16,000 \mathrm{~g}$ for $20 \mathrm{~min}$ at $4^{\circ} \mathrm{C}$. The phenol phase was transferred to a new tube containing four to five times the volume of $0.1 \mathrm{M}$ ammonium acetate in $80 \%(\mathrm{v} / \mathrm{v})$ methanol $(100 \mathrm{~mL})$, and the samples were incubated overnight at $-20^{\circ} \mathrm{C}$. After centrifugation, the pellet was air dried at room temperature and resuspended in an immobilized aqueous solution (8M Urea, 20\% CHAPS, 0.5\% IPG buffer, $0.002 \%$ bromophenol blue, $10 \mathrm{~mL}$ ). Three independent samples were extracted as biological replicates.

2-DE and image analysis were performed as described by Carpentier et al. (2005). The first dimension isoelectric focusing (IEF) was performed with IPG strips (Bio-Rad, USA, pH 4-7, $24 \mathrm{~cm}$ ) with an Ettan IPGphor 3 system (GE Healthcare, USA). The second-dimension electrophoresis was performed on $24 \times 9 \times 24 \mathrm{~cm}$ SDS-PAGE gels (12.5\% acrylamide) without a stacking gel using an Ettan DALT six Large Vertical System (GE Healthcare, USA). A total of six 2-DE gels were loaded with equal amounts of protein $(1.25 \mathrm{mg})$ dissolved in the aqueous solution to a final volume of $425 \mathrm{~mL}$. The gels were stained by $0.1 \%(\mathrm{w} / \mathrm{v}$ ) Coomassie brilliant blue R-250 for 2-3h, then the gel images (Figure S1) were analyzed using the method described by Carpentier et al. (2005), using the Image-Master 2-D Elite software version 4.01 (Amersham Biosciences). Protein spots showed differences in size that were observed in all the replicates were selected as targets.

\section{In-gel digestion and MALDI-TOF/TOF MS analysis}

In-gel tryptic digestion of proteins in the selected spots was performed as in Guha et al. (2013). Samples were analyzed using matrix-assisted laser desorption/ionization (MALDI) time-of-flight (TOF) mass spectrometry (MS) with a proteomics analyzer (4800 Plus, Applied Biosystems, USA), and were internally calibrated using tryptic peptides from auto-digestion. Database searching and PMF (peptide mass fingerprinting) was performed using the in-house Mascot server (http://www.matrix science.com) for matching against to the National Center for Biotechnology non-redundant (NCBI nr) database.

Protein functions were assigned using the protein functional database UniProt (http://www.uniprot.org) and Inter-Pro (http://www.ebi.ac.uk/interpro/) (Apweiler et al. 2002). Proteins identified were then categorized according to their assigned biological functions as described by Bevan et al. (1998). The subcellular locations of the unique proteins identified in this study were predicted using WolfPsort (http://wolfpsort.org) (Wu et al. 2013).

\section{Statistical analysis}

Values are presented as mean \pm standard deviation from at least three individual experiments. Data were assessed by independent samples $t$ test analysis of variance using GraphPad Prism 6 and SPSS 17.0 (SPSS Inc., Chicago, IL, USA). Differences between mid-vein and leaf lamina samples were considered significant at $P<0.05$.

\section{Results}

\section{Variations in photosynthetic parameters}

As shown in Fig. 1, photosynthesis was detected in the mid-vein as well as in the leaf lamina. During senescence, a large decrease trend in the rate of assimilation (A) was observed in the whole blade. The assimilation rate in the lamina decreased by $63 \%(P<0.05)$ on day 35 compared with the day 7 , while in the mid-vein the decrease was smaller (52\%) (Fig. $1 \mathrm{~A}, \mathrm{P}<0.05)$. The reduced transpiration rate $(\mathrm{E})$ in the leaf lamina and mid-vein was approximately $13 \%$ throughout senescence (Fig. 1B, $\mathrm{P}<0.05$ ). The gradual decrease of assimilation and transportation in the mid-vein maybe was due to the stomatal closure induced by senescence. In contrast, as the value of $g_{s}$ slowly dropped, stomatal conductance in the leaf lamina sharply declined (Fig. 1C). This suggests that mid-vein senescence was slower than leaf lamina, which might be due to the decreasing assimilation values. Overall, the internal $\mathrm{CO}_{2}$ concentration ( $\mathrm{Ci}$ ) in the mid-vein was higher, and consistently increased until day 28 , when it began to decrease, whereas $\mathrm{Ci}$ in the leaf lamina started to decrease gradually on day 21 (Fig. 1D). Water use efficiency (WUE) in the mid-vein followed the same trend as the Ci, but slowly declined in the lamina during senescence (Fig. 1E). The variation in vapor pressure deficit (VPD) was opposite that of the transpiration rate (Fig. 1F).

\section{Changes in chlorophyll fluorescence}

As shown in the radar plot graphs of the photosynthesis parameters, when averaged, the overall days of measurement were equivalent to each specific sampling date (Figure 2). In the mid-vein, both the maximum quantum yield for primary photochemistry (TR 0 /ABS) and the potential activity of PSII $\left(F_{V} / F_{0}\right)$ showed a substantial decrease after day 14 , while the electron transport flux (further than $\left.Q_{A}\right)$ per reaction center $(R C)$ at $t=0\left(E T_{0} / R C\right)$ began to decline on day 7. Conversely, the absorption flux per RC (reflecting an average antenna size) (ABS/RC) and the trapped energy flux (leading to $\mathrm{Q}_{\mathrm{A}}$ reduction) per $\mathrm{RC}$ at $\mathrm{t}=0\left(\mathrm{TR} \mathrm{R}_{0} / \mathrm{RC}\right)$ in the mid-vein showed an incremental variation. In addition, $1 / \mathrm{V}_{\mathrm{i}}, \mathrm{RE}_{0} / \mathrm{RC}, \mathrm{PI}_{\text {total }}$ and $\mathrm{PI}$ abs were reduced in the mid-vein during senescence, while $\mathrm{RE}_{0} / \mathrm{ET}_{0}$ and $\mathrm{RE} \mathrm{E}_{0} / \mathrm{CS}_{0}$ rose from day 7 and day 28 , respectively. Thus, the terminal electron acceptors at the $\mathrm{PS}$ I electron acceptor side (RE) driven by PSI were also inhibited. $\mathrm{DI}_{0} / \mathrm{ABS}, \mathrm{DI} / \mathrm{RC}, \mathrm{DI}_{0} / \mathrm{CS}_{0}$ and $\mathrm{DI}_{0} / \mathrm{CS}_{\mathrm{m}}$ values in the mid-vein all started to increase on day 7 , suggesting increased energy dissipation.

\section{Xanthophyll cycle pigment}


The photosynthetic pigment profile in the mid-vein and leaf lamina is shown in Figure 3. Compared to the leaf blade, total chlorophyll (Chl) and carotenoid (Car) levels were approximately 1.23 and 1.71 higher, respectively, in the mid-vein (Figures $3 \mathrm{~A}$ and $3 \mathrm{~B}, \mathrm{P}<0.05$ ). The Car/Chl ratio continuously increased in the mid-vein, whereas the Car/Chl ratio began to decrease on day 28 in the leaf lamina (Figure $3 C$ ). Hence, green mid-veins were characterized by a higher Car/Chl ratio, mainly caused by the increased pools of VAZ cycle $(V A Z=V+A+Z, V$ : violaxantin, $A$ : antheraxanthin, Z: zeaxanthin) components that whose concentrations were determined based on the total chlorophyll and total carotenoids basis. VAZ in the leaf lamina decreased sharply and more rapidly than in the mid-veins (Figure 3D). The average VAZ/Car percentage was 33\%, yet it was significantly higher in the mid-vein (Figure 3E, P<0.05) and the enhanced xanthophyll cycle pool size was accompanied by higher De-epoxidation state (DEPS, $\mathrm{DEPS}=\mathrm{Z}+0.5 \mathrm{~A} / \mathrm{VAZ}$ ) values (Figure $3 \mathrm{~F}$ ), indicating that the cycle was more dynamic in green mid-veins than in the equally exposed leaf lamina.

\section{Detection of ATP content, as well as $\mathrm{Ca}^{2+}$-ATPase and $\mathrm{Mg}^{2+}$-ATPase activities}

ATP content, and $\mathrm{Ca}^{2+}$-ATPase and $\mathrm{Mg}^{2+}$-ATPase activities decreased during senescence (Figure 4). The ATP content in the leaf lamina was markedly lower than in the mid-vein from day 14. In addition, $\mathrm{Ca}^{2+}$-ATPase and $\mathrm{Mg}^{2+}$-ATPase activities in the mid-vein were higher than in the leaf lamina. The decrease in $\mathrm{Mg}^{2+}$-ATPase activity in the mid-vein was much smaller during senescence compared to the leaf lamina, indicating a higher Mg ${ }^{2+}$-ATPase sensitivity in the leaf lamina during senescence.

\section{Protein profiles in the mid-vein and leaf lamina}

Three amino acid metabolism-related proteins were identified (Table 2), including cysteine synthase (spot 37) and glutamine synthases (spot 58 and 104). Spots 58 and 104 were significantly smaller while spot 37 was markedly larger in the mid-vein samples compared with lamina. The differential expression between the mid-vein and leaf lamina would result in a differential capacity for primary metabolism and subsequent plant growth. A total of 15 protein spots were associated with energy processes, representing the largest functional category of the differentially abundant proteins, and proteins involved in photosynthetic processes represented the largest category. Of these were 5 spots whose migration points indicated different pls (isoelectric point) and/or MWs (molecular weight), but were all identified as ribulose-1, 5-bisphosphate carboxylase/oxygenase (RuBisCO) large subunits. This variation in spot position might be due to post-translational modifications, such as glycosylation and phosphorylation, or protein degradation induced by senescence (Li et al. 2014). In the mid-vein compared with lamina, some of these RuBisCO large subunit proteins (spots 123 , 125,128 and 135) showed lower intensity, while another (spot 157) had a higher intensity. RuBisCO activase (spot 92) showed a lower abundance in the mid-vein compared with lamina, while RuBisCO large chain precursor (spot 38) and RuBisCO activase small isoform precursor (spot 70) had a higher intensity. These results indicated that senescence coincides with a major changes in the structure and abundance of RuBisCO in the leaf lamina, which would in turn lead to a comparatively more severe disruption in photosynthesisthan in the mid-vein.

Five notable photosynthetic related proteins were identified as phosphoglycolate phosphatase 1B (PGLP, spot 33), glyceraldehyde-3-phosphate dehydrogenase (spots 69 and 73), atpB gene product (spot 134), NADH dehydrogenase (spot 185) and short-chain type dehydrogenase/reductase (spot 265). The higher intensities of the glyceraldehyde-3-phosphate dehydrogenase and atpB spots in the mid-vein compared with the lamina suggested that photosynthesis is still effective during senescence.

The other two energy-related proteins were annotated as components of the citric acid (TCA) cycle, malate dehydrogenase (spot 50) and dihydrolipoyl dehydrogenase 1 (spot 150). Compared to the leaf lamina, the higher abundance of these proteins in the mid-vein suggests that mid-vein is more dominant during senescence. Five spots were identified as three proteins, and were grouped into the protein synthesis and storage category. Two higher intensity spots (spots 108 and 109) were identified as the reversible chloroplast translational elongation factor Tu, while another translationrelated protein was a putative mediator of RNA polymerase II transcription subunit 37c (spot 247). In addition, Hsp70, which belongs to a class of functionally related proteins involved in the folding and unfolding of other proteins, showed different abundance in different tissues of leaf blade. Finally, three spots were categorized as proteins related to disease/defense: an L-ascorbate peroxidase 2 (spot 24), a thioredoxin-like protein CDSP32 (spot 34) and hypothetical protein Osl-29063 (spot 61) (Table 2). All three proteins were less abundant in the mid-vein, suggesting that the mid-vein suffered less aging stress compared with lamina. We also identified some proteins that were annotated as being associated with signaling transduction but with unknown molecular functions (Table 2).

\section{Discussion}

Senescence is known to involve the degradation of various proteins, but the mechanisms responsible for mid-vein protein degradation remain largely unknown. Shen et al. (2016) found that in rice leaves, the mid-veins have chloroplasts exhibiting active photosynthesis during senescence. In this current study, proteome analysis revealed differential expression of photosynthesis-associated proteins in the mid-vein and leaf lamina, suggesting different photosynthetic performances in the two tissues. The abundance of NADH dehydrogenase [ubiquinone] iron-sulfur protein 1 in the mid-vein was lower than in the lamina, and Guéra and Sabater (2002) found that the total amount of the NADH dehydrogenase complex in pericarp tissue of pepper and tomato fruits is also lower in the ripening stage compared to total plastid protein. Other previous studies have suggested that the NADH dehydrogenase complex may be involved in cyclic electron transport through PSI, probably by balancing the redox state of cyclic electron transporters (Casano et al. 2000; Shikanai et al. 1998). In our study, electron transfer related parameters all showed a decreasing trend during senescence in the mid-vein, which was accompanied by a lower abundance of NADH dehydrogenase. Moreover, the physiological parameters $T R_{0} / A B S$, $F_{V} / F_{0}$ and 
$\mathrm{ET}_{0} / \mathrm{RC}$ related to PSIl showed decreasing values in the mid-vein in late senescence, suggesting that the excitation energy during transfer between subunits of PSII in the mid-vein might be suppressed. We infer that photosynthesis in the mid-vein was perturbed during senescence.

RuBisCO large subunit proteins and RuBisCO activase were less abundant in the mid-vein than in the lamina. RuBisCO is a key enzyme in the Calvin cycle and is a high-abundance protein in plants, contributing to $50-70 \%$ of the total protein content in leaves (Feller et al. 2008). Previous studies showed that a part of the RuBisCO large subunit and RuBisCO activase are present in lower levels in A. thaliana and Trifolium repens (L.) during leaf senescence due to protein degradation (Wilson et al. 2002; Hebeler et al. 2008). Additionally, the change in RuBisCO levels might lead to differences in plasticity of the WUE (Silim et al. 2001). The lower abundance of RuBisCO in the mid-vein compared than in the leaf lamina suggested an overall down-regulation/degradation of the photosynthetic machinery in the mid-vein during senescence. This in turn potentially may lead to a significant decrease in the net photosynthetic rates, while WUE increased in the mid-vein during leaf senescence. As Fig. 1 shows, in the mid-vein, the assimilation rate (A) slowly declined, while the WUE increased. Furthermore, reduced water loss and higher efficiency of water use has been shown to be controlled by effective stomatal conductance (Rivelli et al. 2002) and $\mathrm{CO}_{2}$ enrichment (Chen et al. 1997), and a decrease in g values appears to function as a major determinant of the decrease in carbon assimilation (Petrie et al. 2000; Yokota et al. 2002). Thus, the decline in $g_{s}$ and the competing effects of transpiration and uptake of $\mathrm{Ci}$ in the mid-vein suggests that the effects of senescence stress in the mid-vein were lower than in the leaf lamina, while the degree of perturbation of photosynthetic apparatus and reduced carboxylation efficiency in the mid-vein were lower than in the leaf lamina.

Other energy-related proteins involved in glycolysis, the TCA cycle, and glyoxylate showed a higher abundance in the mid-vein. Upregulation of glycolytic enzymes might lead to enhanced respiration and accelerated consumption of sugars that serve as energy reserves (Jespersen et al. 2015). GAPDH enzymes are involved in glycolysis during respiration (Plaxton 1996). Expression of GAPDH in plants leads to decreased levels of reactive oxygen species (ROS) and enhanced tolerance to heat shock-induced cell death (Baek et al. 2008). Thus, the photosynthetic ability seems to be less affected by senescence in the mid-vein. The TCA cycle is composed of many enzymes linking the oxidation product of pyruvate and malate to $\mathrm{CO}_{2}$ with the generation of NADH for oxidation by the mitochondrial respiratory chain (Fernie et al. 2004). The higher abundance of malate dehydrogenase $(\mathrm{MDH})$ and dihydrolipoyl dehydrogenase 1 in the mid-vein suggest that the TCA cycle was minimally affected compared to the lamina by senescence in the mid-vein. In addition, the high abundance of phosphoglycolate phosphatase 1B has been shown to be involved in the evolution of the photorespiratory glycolate mechanism in higher plants (Fischer and Feller 1994). The higher abundance of phosphoglycolate phosphatase 1B in the mid-vein may serve to maintain normal photorespiration and ensure glutathione production during senescence in the mid-vein, thus further protecting it from damage by senescence.

A higher abundance of the atpB gene product was also detected in the mid-vein compared with the lamina, suggesting that an increased ATP supply may meet increased energy demands caused by stress, thereby alleviating cellular stress caused by senescence. Accumulation of the atpB protein may provide a signal to increase ATP synthesis in order to tolerate stress (Sobhanian et al. 2011), which could be beneficial for the rice plants during senescence. In our study, ATP content, as well as $\mathrm{Ca}^{2+}$-ATPase and $\mathrm{Mg}^{2+}$-ATPase activity in the mid-vein, were higher than in the leaf lamina during late senescence, suggesting a more progressed senescence in the leaf lamina. We also confirmed that photosynthesis in the mid-vein was higher than in the leaf lamina, and the dissipated energy indexes, $\mathrm{DI}_{0} / \mathrm{RC}, \mathrm{DI}_{0} / \mathrm{ABS}, \mathrm{DI}_{0} / \mathrm{CS}_{0}$ and $\mathrm{DI}_{0} / \mathrm{CS}_{\mathrm{m}}$ were higher. We conclude that the higher stress caused by aging was converted into heat dissipated energy in the mid-vein, which may represent a self-protection strategy to avoid aging stress. Carotenoids also play a role in delaying senescence in leaves (Biswal., 1995), while xanthophylls are important for light harvesting as well as for processing excess excitation pressure through a singlet- and triplet state energy quenching mechanism. We observed a smaller values of fresh weight-based total $\mathrm{Chl}$ and Car, but a in the mid-vein than in the leaf lamina (Fig. 3). Demmig-Adams (1996) showed that an increased Car/Chl ratio may reflect a higher need for light capture. The higher total Car/Chl increase in the mid-vein compared with the lamina suggests either an increased need for dissipation of extra excitation energy or an increased requirement for photon capture, which were shown by the increased pools of VAZ cycle components (Choudhury and Behera 2001; Munne-Bosch and Penuelas 2003). The greater VAZ pool size in the mid-vein compared with the lamina combined with a higher DEPS revealed that the cycle is more active under senescence stress in the mid-vein than in the leaf lamina. Similar results have reported in studies of apple peels (Cheng and Ma 2004), where the enhanced pool and functionality of the xanthophyll cycle components were correlated with a higher thermal dissipation of excess excitation energy shown by the fruit (Cheng and Ma 2004). Thus, the xanthophyll cycle was more active in the mid-vein and favored energy dissipation, which effectively relieved the loss due to excessive accumulation of energy.

The proteins related to disease/defense, like L-ascorbate peroxidase 2 and thioredoxin-like protein CDS 32 were less abundant in the mid-vein compared with the lamina, which in turn lowered the oxidation levels and stress damage. Hsp70 and the elongation factor both assist in protein folding and refolding and are distributed ubiquitously in all living organisms (Kato and Sakamoto 2013). The high abundance of Hsp70 prevents aggregation of denatured proteins and helps in refolding non-native proteins (Sherman et al. 2007; Timperio et al. 2008; Onda and Kobori 2014). We conclude that protein degradation and synthesis in the mid-vein was hampered by a high abundance of Hsp70 and elongation factor. Accordingly, during late senescence the photosynthetic capacity was greater and the senescence rate was slower in the mid-vein than in the leaf lamina.

\section{Conclutions}

Based on the above results and discussions, we conclude that the cells around the mid-vein vascular bundle may have a relatively complete photosynthetic system that is important in late senescence (Fig. 7). Compared to the leaf lamina, the mid-vein may dissipate more excess energy in

Page $6 / 20$ 
the form of heat through the xanthophyll cycle, which may be associated with a longer and more active photosynthetic capacity during the latter part of senescence. In addition, compared to the leaf lamina, various energy-related proteins were more abundant in the mid-vein than in the lamina, such as ATP synthase-related enzymes and TCA cycle-related enzymes. Meanwhile, some disease/defense-related proteins were less abundant in the midvein, suggesting less cellular damage in this tissue than in the leaf lamina. Taken together, these results suggest that the photosynthetic pathway and energy metabolism were less affected by senescence in the mid-vein than in the lamina. We conclude that the mid-vein and leaf lamina of rice LYP9 age differently. The mid-vein may play an important role during leaf senescence, and our data might provide new insights into the underlying mechanisms of senescence and the physiology of the rice mid-vein.

\section{A List Of Abbreviations}

\begin{tabular}{|c|c|}
\hline A & assimilation rate \\
\hline A & antheraxanthin \\
\hline a.m. & ante meridiem \\
\hline A. thaliana & Arabidopsis thaliana \\
\hline Car & carotenoid \\
\hline Chl & chlorophyll \\
\hline $\mathrm{Ci}$ & internal $\mathrm{CO}_{2}$ concentration \\
\hline $\mathrm{CO}_{2}$ & carbon dioxide \\
\hline DEPS & De-epoxidation state \\
\hline $\mathrm{E}$ & transpiration rate \\
\hline GAPDH & glyceraldehyde-3-phosphate dehydrogenase \\
\hline$g_{s}$ & stomatal conductance \\
\hline HPLC & high performance liquid chromatography \\
\hline IPG & immobilized pH gradient \\
\hline LYP9 & Liangyoupei9 \\
\hline MALDI & matrix-assisted laser desorption/ionization \\
\hline $\mathrm{MDH}$ & malate dehydrogenase \\
\hline MS & mass spectrometry \\
\hline MW & molecular weight \\
\hline 2-DE & two-dimensional gel electrophoresis \\
\hline $\mathrm{pl}$ & isoelectric point \\
\hline PMF & peptide mass fingerprinting \\
\hline PS I & photosystem I \\
\hline PS ॥ & photosystem II \\
\hline RuBisCO & ribulose-1, 5-bisphosphate carboxylase/oxygenase \\
\hline $\mathrm{RC}$ & reaction center \\
\hline ROS & reactive oxygen species \\
\hline SDS & sodium dodecyl sulfate \\
\hline TOF & time-of-flight \\
\hline V & violaxantin \\
\hline VPD & vapor pressure deficit \\
\hline WUE & Water use efficiency \\
\hline Z & zeaxanthin \\
\hline
\end{tabular}




\section{Declarations}

\section{DECLARATIONS}

- Ethical Approval and Consent to participate: Not applicable.

- Consent for publication: Not applicable.

- Availability of supporting data: The data will be shared.

- Competing interests: Not applicable.

- Funding: This work was supported by the National Natural Science Foundation of China (grant no. 31271621), the Priority Academic Program Development of Jiangsu Higher Education Institutions (PAPD), and Jiangsu Agriculture Science and Technology Innovation Fund (JASTIF, grant no. CX181001).

- Authors' contributions: Gao ZP and Chen GX designed the study. Xu ML, Gao ZP, and Zhang HZ performed the experiments. Gao ZP and Xu ML analyzed the data and wrote the manuscript.

- Acknowledgements: Not applicable.

- • Authors' information: Zhiping Gao: ketty-1982@163.com; Minli Xu: 906833770@qq.com; Haizi Zhang: zhanghaizi@163.com; Guoxiang Chen: 08295@njnu.edu.cn.

\section{References}

1. Apweiler R, Biswas M, Fleischmann W, Kanapin A, Karavidopoulou Y (2002) Proteome Analysis Database: online application of InterPro and CluSTr for the functional classification of proteins in whole genomes. Nucleic Acids Res 29:44-48

2. Arnon DI (1949) Copper enzymes in isolated chloroplasts. Polyphenoloxidase in beta vulgaris. Plant Physiol 24:1-16

3. Aschan G, Pfanz H (2003) Non-foliar photosynthesis-a strategy of additional carbon acquisition. Flora 198:81-97

4. Aubry S, Brown NJ, Hibberd MJ (2011) The role of proteins in $C_{3}$ plants prior to their recruitment into the $C_{4}$ pathway. J Exp Bot 62:3049-3059

5. Baek D, Jin Y, Jeong JC, Lee HJ, Moon H, Lee J (2008) Suppression of reactive oxygen species by glyceraldehyde-3-phosphate dehydrogenase. Phytochemistry 69:333-338

6. Bevan M, Bancroft I, Bent E et al (1998) Analysis of $1.9 \mathrm{Mb}$ of contiguous sequence from chromosome 4 of Arabidopsis thaliana. Nature 391:485-488

7. Bispo WMDS, Araujo L, Moreira WR, Silva LDC, Rodrigues F (2016) Differential leaf gas exchange performance of mango cultivars infected by different isolates of ceratocystis fimbriata. Sci Agr 73:150-158

8. Biswal B (1995) Caroenoid catabolism during leaf senescence and its control by light. J Exp Bot 30:3-13

9. Biswal B, Mohapatra PK, Biswal UC, Raval MK (2012) Leaf senescence and transformation of chloroplasts to gerontoplasts. Photosynthesis $34: 217-230$

10. Clermont MG (2003) Book review: Chloroplast biogenesis: from proplastid to gerontoplast. Photosynth Res 82:197-198

11. Biswal UC, Prasanna M (1978) Changes in the ability of photophosphorylation and activities of surface-bound adenosine triphosphatase and ribulose diphosphate carboxylase of chloroplasts isolated from the barley leaves senescing in darkness. Physiol Plant 44:127-133

12. Brown NJ, Palmer BG, Stanley S, Hajaji H, Janacek SH, Astley HM, Parsley K, Kajala K, Quick WP, Trenkamp S, Fernie AR, Maurino VG, Hibberd JM (2010) $\mathrm{C}_{4}$ acid decarboxylases required for $\mathrm{C}_{4}$ photosynthesis are active in the mid-vein of the $\mathrm{C}_{3}$ species Arabidopsis thaliana, and are important in sugar and amino acid metabolism. Plant J 61:122-133

13. Carpentier SC, Witters E, Laukens K, Deckers P, Swennen R, Panis B (2005) Preparation of protein extracts from recalcitrant plant tissues: an evaluation of different methods for two-dimensional gel electrophoresis analysis. Proteomics 5:2497-2507

14. Casano LM, Zapata JM, Martín M, Sabater B (2000) Chlororespiration and poising of cyclic electron transport. Plastoquinone as electron transporter between thylakoid nadh dehydrogenase and peroxidase. J Biol Chem 275:942-948

15. Chen K, Hu GQ, Keutgen N, Blanke M, Lenz F (1997) Effects of $\mathrm{CO}_{2}$ concentration on strawberry. ii. leaf photosynthetic function. Angew Bot 71:173-178

16. Cheng L, Ma F (2004) Diurnal operation of the xanthophyll cyle and the antioxidant system in Apple Peel. J Am Soc Hortic Sci 129:313-320

17. Choudhury NK, Behera RK (2001) Photoinhibition of photosynthesis: Role of carotenoids in photoprotection of chloroplast constituents. Photosynthetica 39:481-488

18. Demmig-Adams B, Gilmore A, Adams W (1996) In vivo functions of carotenoids in higher plants. Faseb J 10:403-412

19. Deoa PM, Biswalb B (2001) Response of senescing cotyledons of clusterbean to water stress in moderate and low light: possible photoprotective role of b-carotene. Physiol Plantarum 112:47-54

20. Dima E, Manetas Y, Psaras GK (2006) Chlorophyll distribution pattern in inner stem tissues: evidence from epifluorescence microscopy and reflectance measurements in 20 woody species. Trees 20:515-521

Page $8 / 20$ 
21. Feller U, Anders I, Mae T (2008) Rubiscolytics: fate of Rubisco after its enzymatic function in a cell is terminated. J Exp Bot 59:1615-1624

22. Fischer A, Feller U (1994) Senescence and protein degradation in leaf segments of young winter wheat: influence of leaf age. J Exp Bot 45:103109

23. Gao ZP, Shen WJ, Chen GX (2018) Uncovering $C_{4}$-like photosynthesis in $C_{3}$ vascular cells. J Exp Bot 69:3531-3540

24. Ginsburg S, Schellenberg M, Matile P (1994) Cleavage of chlorophyll-porphyrin: requirement for reduced ferredoxin and oxygen. Plant Physiol 105:545-554

25. Grover A (1993) How do senescing leaves lose photosynthetic activity? Science 64, 226-233

26. Guéra A, Sabater B (2002) Changes in the protein and activity levels of the plastid, NADH-plastoquinone-oxidoreductase complex during fruit development. Plant Physiol Bioch 40:423-429

27. Guha A, Sengupta D, Reddy AR (2013) Polyphasic chlorophyll a fluorescence kinetics and leaf protein analyses to track dynamics of photosynthetic performance in mulberry during progressive drought. J Photoch Photobiol B 119:71-83

28. Harding SA, Guikema JA, Paulsen GM (1990) Photosynthetic decline from high temperature stress during maturation of wheat. Plant Physiol 92:648-653

29. Hebeler R, Oeljeklaus S, Reidegeld KA, Eisenacher M, Stephan C, Sitek B, Stuhler K, Meyer HE, Sturre MJ, Dijkwel PP, Warscheid B (2008) Study of early leaf senescence in Arabidopsis thaliana by quantitative proteomics using reciprocal ${ }^{14} \mathrm{~N} /{ }^{15} \mathrm{~N}$ labeling and difference gel electrophoresis. Mol Cell proteomics 7:108-120

30. Hibberd JM, Covshoff S (2010) The regulation of gene expression required for $C_{4}$ photosynthesis. Annu Rev Plant Biol 61:181-207

31. Hibberd JM, Quick WP (2002) Characteristics of $C_{4}$ photosynthesis in stems and petioles of $C_{3}$ owering plants. Nature 415:451-454

32. Humbeck K, Quast S, Krupinska K (1996) Functional and molecular changes in the photosynthetic apparatus during senescence of flag leaves from field-grown barley plants. Plant Cell Environ 19:337-344

33. Jespersen D, Huang B (2015) Proteins associated with heat-induced leaf senescence in creeping bentgrass as affected by foliar application of nitrogen, cytokinins, and an ethylene inhibitor. Proteomics 15:798-812

34. Kalachanis D, Manetas Y (2010) Analysis of fast chlorophyll fluorescence rise (O-K-J-I-P) curves in green fruits indicates electron flow limitations at the donor side of PSII and the acceptor sides of both photosystems. Physiol Plantarum 139:313-323

35. Kato Y, Sakamoto W (2013) Plastid protein degradation during leaf development and senescence: role of proteases and chaperones. Adv Photosynthesis Resp 36:453-477

36. Kirst H, Garcia-Cerdan JG, Zurbriggen A, Ruehle T, Melis A (2012) Truncated photosystem chlorophyll antenna size in the green microalga Chlamydomonas reinhardtii upon deletion of the TLA3-CPSRP43 gene. Plant Physiol 160, 2251-2260

37. Kusaba M, Ito H, Morita R, lida S, Sato Y, Fujimoto M, Kawasaki S, Tanaka R, Hirochika H, Nishimura M, Tanaka A (2007) Rice NON-YELLOW COLORING1 is involved in light-harvesting complex II and grana degradation during leaf senescence. Plant Cell 19:1362-1375

38. Li W, Tang X, Xing J, Sheng X, Zhan W (2014) Proteomic analysis of differentially expressed proteins in Fenneropenaeus chinensis hemocytes upon white spot syndrome virus infection. PLoS ONE 9:e89962

39. Lichtenthaler H, Wellburn A (1983) Determinations of total carotenoids and chlorophylls a and b of leaf extracts in different solvents. Biochem Soc T 11:591-592

40. Lu C, Lu Q, Zhang J, Kuang T (2001) Characterization of photosynthetic pigment composition, photosystem II photochemistry and thermal energy dissipation during leaf senescence of wheat plants grown in the field. J Exp Bot 52:1805-1810

41. Ma J, Lv C, Xu M, Chen G, Lv C, Gao Z (2016) Photosynthesis performance, antioxidant enzymes, and ultrastructural analyses of rice seedlings under chromium stress. Environ Sci Pollut Res 23:1768-1778

42. Manetas $Y$ (2004) Probing corticular photosynthesis through in vivo chlorophyll fluorescence measurements: evidence that high internal $\mathrm{CO}_{2}$ levels suppress electron flow and increase the risk of photoinhibition. Physio Plantarum 120:509-517

43. Mohapatra PK, Patro L, Raval MK, Ramaswamy NK, Biswal UC, Biswal B (2010) Senescence-induced loss in photosynthesis enhances cell wall beta-glucosidase activity. Physiol Plant 138:346-355

44. Munne-Bosch S, Penuelas J (2003) Photo- and antioxidative protection during summer leaf senescence in pistacia lentiscus I. grown under mediterranean field conditions. Ann Bot-London 9:385-391

45. Nwugo CC, Huerta AJ (2011) The effect of silicon on the leaf proteome of rice (Oryza sativa L.) plants under cadmium-stress. J Proteome Res 10:518-528

46. Onda Y, Kobori Y (2014) Differential activity of rice protein disulfide isomerase family members for disulfide bond formation and reduction. FEBS Open Bio 4:730-734

47. Pavlovič A, Singerová L, Demko V, Hudák J (2009) Feeding enhances photosynthetic efficiency in the carnivorous pitcher plant Nepenthes talangensis. Ann Bot 104:307-314

48. Panda D, Sarkar RK (2013) Natural leaf senescence: probed by chlorophyll fluorescence, $\mathrm{CO}_{2}$, photosynthetic rate and antioxidant enzyme activities during grain filling in different rice cultivars. Physiol Mol Biol Pla 19:43-51

Page 9/20 
49. Petrie PR, Trought MCT, Howell GS (2000) Influence of leaf ageing, leaf area and crop load on photosynthesis, stomatal conductance and senescence of grapevine (vitis vinifera I. cv. pinot noir) leaves. Vitis 39, 31-36

50. Pfanz H, Aschan G, Langenfeld-Heyser R, Wittmann C, Loose M (2002) Ecology and ecophysiology of tree stems: corticular and wood photosynthesis. Naturwissenschaften 89:147-162

51. Plaxton WC (1996) The organization and regulation of plant glycolysis. Ann Rev Plant Physiol Plant Mol Biol 47, 185-214

52. Prakash J, Baig M, Mohanty P (1998) Alterations in electron transport characteristics during senescence of Cucumis cotyledonary Leaves. Analysis of the effects of inhibitors Photosynthetica 35:345-352

53. Quirino BF, Noh YS, Himelblau E, Amasino RM (2000) Molecular aspects of leaf senescence. Trends Plant Sci 5:278-282

54. Rivelli AR, Loverlli S, Perniola M (2002) Effects of salinity on gas exchange, water relations and growth of sunflower (Helianthus annuus). Funct Plant Biol 29:1405-1415

55. Sage $R$ (2004) The evolution of $C_{4}$ photosynthesis. New Phytol 131:1834-1842

56. Shen W, Ye L, Ma J, Yuan Z, Zheng B, Lv C, Zhu Z, Chen X, Gao Z, Chen G (2016) The existence of C -bundle-sheath-like photosynthesis in the mid-vein of $C_{3}$ rice. Rice $9,1-14$

57. Sherman MY, Sherman M, Gabai V, O'Callaghan C, Yaglom J (2007) Molecular chaperones regulate p53 and suppress senescence programs. Febs Letters 581:3711-3715

58. Shikanai T, Endo T, Hashimoto T, Yamada Y, Asada K, Yokota A (1998) Directed disruption of the tobacco ndhB gene impairs cyclic electron flow around photosystem I. Proc Natl Acad Sci USA 95:9705-9709

59. Silim S, Guy R, Patterson T, Livingston N (2001) Plasticity in water-use efficiency of Picea sitchensis, P.glauca and their natural hybrids. Oecologia 128, 317-325

60. Sobhanian H, Aghaei K, Komatsu S (2011) Changes in the plant proteome resulting from salt stress: toward the creation of salt-tolerant crops? J Proteomics 74:1323-1337

61. Strasserf RJ, Srivastava A, Govindjee (1995) Polyphasic chlorophyll a, fluorescence transient in plants and cyanobacteria. Photochem Photobiol $61: 32-42$

62. Timperio AM, Egidi MG, Zolla L (2008) Proteomics applied on plant abiotic stresses: role of heat shock proteins (HSP). J Proteomics 71:391-411

63. Vallejos R, Arana J, Ravizzini R (1983) Changes in activity and structure of the chloroplast proton ATPase induced by illumination of spinach leaves. J Biol Chem 258:7317-7321

64. Wang W, Vignani R, Scali M, Cresti M (2006) A universal and rapid protocol for protein extraction from recalcitrant plant tissues for proteomic analysis. Electrophoresis 27:2782-2786

65. Wang FB, Liu JC, Chen MX, Zhou LJ, Li ZW, Zhao Q, Pan G, Zaidi SHR, Cheng FM (2016) Involvement of abscisic acid in PSII photodamage and D1 protein turnover for light-induced premature senescence of rice flag leaves. Plos One 11:1-25

66. Wilson KA, McManus MT, Gordon ME, Jordan TW (2002) The proteomics of senescence in leaves of white clover, Trifolium repens (L.). Proteomics 2, 1114-1122

67. Wright AH, DeLong JM, Gunawardena AH, Prange RK (2011) The interrelationship between the lower oxygen limit, chlorophyll fluorescence and the xanthophyll cycle in plants. Photosynth Res 107:223-235

68. Wu L, Han Z, Wang S, Wang X, Sun A, Zu X, Chen Y (2013) Comparative proteomic analysis of the plant-virus interaction in resistant and susceptible ecotypes of maize infected with sugarcane mosaic virus. J Proteomics 89:124-140

69. Yokota A, Kawasaki S, Iwano M, Nakamura C, Miyake C, Akashi K (2002) Citrulline and DRIP-1 Protein (ArgE Homologue) in drought tolerance of wild watermelon. Ann Bot-London 89:825-832

70. Yu GH, Li W, Yuan ZY, Cui HY, Lv CG, Gao ZP, Han B, Gong YZ, Chen GX (2012) The effects of enhanced UV-B radiation on photosynthetic and biochemical activities in super-high-yield hybrid rice Liangyoupeijiu at the reproductive stage. Photosynthetica 51:33-44

71. Zhang CJ, Chen GX, Gao XX, Chu CJ (2006) Photosynthetic decline in flag leaves of two field-grown spring wheat cultivars with different senescence properties. S Afr J Bot 72:15-23

72. Zhu X, Chen G, Zhang C (2001) Photosynthetic electron transport, photophosphorylation, and antioxidants in two ecotypes of reed (phragmites communis trin.) from different habitats. Photosynthetica 39:183-189

\section{Tables}

Table 1 Formulae and definitions of the selected chlorophyll a (Chl a) fluorescence parameters 


\begin{tabular}{|c|c|}
\hline Fluorescence parameter & Definition \\
\hline$V_{1}=\left(F_{1}-F_{0}\right) /\left(F_{M}-F_{0}\right)$ & Relative variable fluorescence at step I \\
\hline $1 / V_{1}=\left(F_{M}-F_{0}\right) /\left(F_{1}-F_{0}\right)$ & $\begin{array}{l}\text { The maximal amplitude of IP phase reflecting the relative pool size of the final electron acceptors in } \\
\text { PSI }\end{array}$ \\
\hline$\varphi_{\mathrm{P} 0}=\mathrm{TR}_{0} / \mathrm{ABS}=1-\mathrm{F}_{0} / \mathrm{F}_{\mathrm{M}}$ & Maximum quantum yield for primary photochemistry at $t=0$ \\
\hline$\varphi_{\mathrm{D} 0}=\mathrm{DI}_{0} / \mathrm{ABS}=1-\varphi_{\mathrm{P} 0}=\mathrm{F}_{0} / \mathrm{F}_{\mathrm{M}}$ & Quantum yield for energy dissipation at $t=0$ \\
\hline $\mathrm{F}_{\mathrm{V}} / \mathrm{F}_{0}$ & A value that is proportional to the activity of the water-splitting complex on the donor side of PS II \\
\hline$\Psi_{\mathrm{E} 0}=\mathrm{ET}_{0} / \mathrm{TR}_{0}=1-\mathrm{V}_{\mathrm{J}}$ & $\begin{array}{l}\text { Efficiency/probability with which a trapped excitation can move an electron into the electron transport } \\
\text { chain beyond } \mathrm{Q}_{\mathrm{A}}^{-}\end{array}$ \\
\hline$\delta_{\mathrm{R} 0}=\mathrm{RE}_{0} / \mathrm{ET}_{0}=\left(1-\mathrm{V}_{\mathrm{l}}\right)\left(1-\mathrm{V}_{\mathrm{J}}\right)$ & $\begin{array}{l}\text { Efficiency/probability with which an electron can move from the reduced intersystem electron } \\
\text { acceptors to the PSI end electron acceptors }\end{array}$ \\
\hline$A B S / R C=M_{0} / V_{J} / \varphi_{P 0}$ & Absorption flux per RC (reflecting an average antenna size) \\
\hline $\mathrm{TR}_{0} / \mathrm{RC}=\mathrm{M}_{0} / \mathrm{V}_{\mathrm{J}}$ & Trapped energy flux (leading to $\mathrm{Q}_{\mathrm{A}}$ reduction) per $\mathrm{RC}$ at $\mathrm{t}=0$ \\
\hline $\mathrm{ET}_{0} / \mathrm{RC}=\mathrm{M}_{0}\left(1 / \mathrm{V}_{\mathrm{J}}\right)\left(1-\mathrm{V}_{\mathrm{J}}\right)$ & Electron transport flux (further than $\mathrm{Q}_{A}$ ) per $\mathrm{RC}$ at $\mathrm{t}=0$ \\
\hline $\mathrm{RE}_{0} / \mathrm{RC}=\mathrm{M}_{0}\left(1 / \mathrm{V}_{\mathrm{J}}\right) \Psi_{\mathrm{E} 0} \delta_{\mathrm{R} 0}$ & Electron flux reduction end electron acceptors at the PSI acceptor side per $\mathrm{RC}$ at $\mathrm{t}=0$ \\
\hline $\mathrm{DI} \mathrm{I}_{0} / \mathrm{RC}=(\mathrm{ABS} / \mathrm{RC})-\left(\mathrm{TR}_{0} / \mathrm{RC}\right)$ & Dissipated energy flux per $\mathrm{RC}$ at $\mathrm{t}=0$ \\
\hline $\mathrm{RE}_{0} / \mathrm{CS}_{0}=\left(\mathrm{RE}_{0} / \mathrm{ET}_{0}\right)\left(\mathrm{ET}_{0} / \mathrm{CS}_{0}\right)$ & Electron flux reduction end electron acceptors at the PSI acceptor side per cross section at $t=0$ \\
\hline $\mathrm{DI}_{0} / \mathrm{CSm}=(\mathrm{ABS} / \mathrm{CSm})-\left(\mathrm{TR}_{0} / \mathrm{CSm}\right)$ & Dissipation per cross section, approximated by $F_{M}$ \\
\hline $\begin{array}{l}\mathrm{PI}_{\text {total }}=(\mathrm{RC} / \mathrm{ABS})\left[\varphi_{\mathrm{P} 0} /\left(1-\varphi_{\mathrm{PO}}\right)\right]\left[\psi_{\mathrm{E} 0} /(1-\right. \\
\left.\left.\psi_{\mathrm{E} 0}\right)\right]\left[\delta_{\mathrm{R} 0} /\left(1-\delta_{\mathrm{R} 0}\right)\right]\end{array}$ & $\begin{array}{l}\text { Performance index (potential) for energy conservation from exciton to the reduction of PSI end } \\
\text { acceptors }\end{array}$ \\
\hline $\begin{array}{l}\text { Plabs }=(R C / A B S) \times\left(\varphi_{P 0} /\left(1-\varphi_{P 0}\right)\right) \times \\
\left(\Psi_{0} /\left(1-\Psi_{0}\right)\right)\end{array}$ & Performance index on an absorption basis \\
\hline
\end{tabular}

Subscript "0" (or "o" when written after another subscript) indicates that the parameter refers to the onset of illumination, when all reaction centers (RCs) are assumed to be open.

Table 2. Differentially present proteins identified from the mid-vein and leaf lamina by mass spectrometry (MS) 


\begin{tabular}{|c|c|c|c|c|c|c|c|c|}
\hline Biological process & \multirow{2}{*}{$\begin{array}{l}\text { Match } \\
\text { ID }^{\mathrm{a}}\end{array}$} & \multirow[t]{2}{*}{ Identified protein ${ }^{b}$} & \multirow[t]{2}{*}{ Accession No. ${ }^{c}$} & \multirow[t]{2}{*}{$\mathrm{Pi} / \mathrm{Mr}^{\mathrm{d}}$} & \multirow[t]{2}{*}{$\mathrm{MO}^{\mathrm{e}}$} & \multirow[t]{2}{*}{$\mathrm{PM}^{\mathrm{f}}$} & \multirow[t]{2}{*}{$\mathrm{SC} \% \mathrm{~g}$} & \multirow[t]{2}{*}{ Variation } \\
\hline Metabolism & & & & & & & & \\
\hline Amimo acid & 37 & $\begin{array}{l}\text { Cysteine synthase [Oryza } \\
\text { sativa.L Japonica] }\end{array}$ & Q9XEA6.2 & $5.39 / 33.93$ & 32 & 29 & 9 & up \\
\hline & 104 & $\begin{array}{l}\text { PREDICTED: glutamine } \\
\text { synthetase, chloroplastic } \\
\text { [Oryza sativa.L Japonica } \\
\text { Group] }\end{array}$ & XP_015635322.1 & $5.96 / 46.96$ & 132 & 59 & 13 & down \\
\hline & 58 & $\begin{array}{l}\text { putative precursor } \\
\text { chloroplastic glutamine } \\
\text { synthetase [Oryza } \\
\text { sativa.L Japonica Group] }\end{array}$ & AAL87183.1 & $6.18 / 49.77$ & 85 & 38 & 8 & down \\
\hline \multicolumn{9}{|l|}{ Energy } \\
\hline Citrate cycle & 60 & $\begin{array}{l}\text { PREDICTED: malate } \\
\text { dehydrogenase, } \\
\text { mitochondrial [Oryza } \\
\text { sativa.L Japonica Group] }\end{array}$ & XP_015639465.1 & $8.22 / 35.64$ & 73 & 26 & 7 & up \\
\hline & 150 & $\begin{array}{l}\text { PREDICTED: dihydrolipoyl } \\
\text { dehydrogenase 1, } \\
\text { mitochondrial [Oryza } \\
\text { sativa.L Japonica Group] }\end{array}$ & XP_015611017.1 & $7.21 / 53.01$ & 68 & 45 & 8 & up \\
\hline Photosythesis & 38 & $\begin{array}{l}\text { Ribulose bisphosphate } \\
\text { carboxylase large chain } \\
\text { precursor, putative [Oryza } \\
\text { sativa.L Japonica Group] }\end{array}$ & ABA96140.2 & $9.04 / 56.55$ & 88 & 32 & 6 & up \\
\hline & 69 & $\begin{array}{l}\text { glyceraldehyde-3- } \\
\text { phosphate } \\
\text { dehydrogenase, partial } \\
\text { [Oryza sativa.L Indica } \\
\text { Group] }\end{array}$ & ABR25332.1 & $6.95 / 23.79$ & 87 & 44 & 20 & up \\
\hline & 70 & $\begin{array}{l}\text { RuBisCO activase small } \\
\text { isoform precursor [Oryza } \\
\text { sativa.L] }\end{array}$ & BAA97584.1 & $5.85 / 48.13$ & 89 & 36 & 8 & up \\
\hline & 73 & $\begin{array}{l}\text { PREDICTED: } \\
\text { glyceraldehyde-3- } \\
\text { phosphate } \\
\text { dehydrogenase B, } \\
\text { chloroplastic [Oryza } \\
\text { sativa.L Japonica Group] }\end{array}$ & XP_015630808.1 & $6.22 / 47.54$ & 80 & 30 & 6 & up \\
\hline & 92 & $\begin{array}{l}\text { ribulose-1,5-bisphosphate } \\
\text { carboxylase/oxygenase } \\
\text { activase [Oryza sativa.L } \\
\text { Japonica Group] }\end{array}$ & AAC28134.1 & $5.85 / 48.06$ & 111 & 67 & 15 & down \\
\hline & 123 & $\begin{array}{l}\text { ribulose-1,5-bisphosphate } \\
\text { carboxylase/oxygenase } \\
\text { large subunit, partial } \\
\text { [Oryza sativa.L] }\end{array}$ & ADD48129.1 & $7.00 / 26.50$ & 70 & 31 & 13 & down \\
\hline & 125 & $\begin{array}{l}\text { ribulose-1,5-bisphosphate } \\
\text { carboxylase/oxygenase } \\
\text { large subunit, partial } \\
\text { [Oryza sativa.L] }\end{array}$ & AFK09923.1 & $7.00 / 24.23$ & 71 & 32 & 14 & down \\
\hline & 128 & $\begin{array}{l}\text { Os12g0207600 [Oryza } \\
\text { sativa Japonica Group] }\end{array}$ & BAF29408.1 & $9.01 / 59.56$ & 48 & 32 & 6 & down \\
\hline & 134 & $\begin{array}{l}\text { atpB gene product [Oryza } \\
\text { sativa.L] }\end{array}$ & AAA84588.1 & $5.30 / 53.98$ & 150 & 55 & 11 & up \\
\hline & 135 & $\begin{array}{l}\text { ribulose-1,5-bisphosphate } \\
\text { carboxylase/oxygenase } \\
\text { large subunit, partial } \\
\text { [Oryza sativa.L] }\end{array}$ & CAG34174.1 & $6.23 / 63.33$ & 71 & 32 & 6 & down \\
\hline & 157 & $\begin{array}{l}\text { Putative rbcL; RuBisCO } \\
\text { large subunit from } \\
\text { chromosome } 10 \\
\text { chloroplast insertion }\end{array}$ & AAM08604.1 & $6.45 / 53.43$ & 57 & 32 & 6 & up \\
\hline
\end{tabular}


[Oryza sativa.L Japonica Group]

\begin{tabular}{|c|c|c|c|c|c|c|c|c|c|}
\hline & & 185 & $\begin{array}{l}\text { PREDICTED: NADH } \\
\text { dehydrogenase } \\
\text { [ubiquinone] iron-sulfur } \\
\text { protein 1, mitochondrial } \\
\text { [Oryza sativa.L Japonica } \\
\text { Group] }\end{array}$ & XP_015630641.1 & $6.15 / 88.21$ & 172 & 69 & 8 & down \\
\hline & & 265 & $\begin{array}{l}\text { PREDICTED: short-chain } \\
\text { type } \\
\text { dehydrogenase/reductase } \\
\text { [Oryza sativa.L Japonica } \\
\text { Group] }\end{array}$ & XP_015613174.1 & $6.17 / 26.85$ & 43 & 35 & 13 & up \\
\hline & Glyoxylate & 33 & $\begin{array}{l}\text { PREDICTED: } \\
\text { phosphoglycolate } \\
\text { phosphatase 1B, } \\
\text { chloroplastic [Oryza } \\
\text { sativa.L Japonica Group] }\end{array}$ & XP_015636788.1 & $6.75 / 39.81$ & 77 & 45 & 12 & up \\
\hline \multirow[t]{5}{*}{$\begin{array}{l}\text { Protein } \\
\text { sythesis and } \\
\text { stroage }\end{array}$} & $\begin{array}{l}\text { Translation } \\
\text { factor }\end{array}$ & 108 & $\begin{array}{l}\text { chloroplast translational } \\
\text { elongation factor Tu } \\
\text { [Oryza sativa.L Japonica } \\
\text { Group] }\end{array}$ & AAF15312.1 & $6.05 / 50.55$ & 90 & 45 & 9 & up \\
\hline & & 109 & $\begin{array}{l}\text { PREDICTED: elongation } \\
\text { factor Tu, chloroplastic } \\
\text { [Oryza sativa.L Japonica } \\
\text { Group] }\end{array}$ & XP_015627061.1 & $6.19 / 50.61$ & 50 & 31 & 5 & up \\
\hline & $\begin{array}{l}\text { Translation } \\
\text { control }\end{array}$ & 247 & $\begin{array}{l}\text { PREDICTED: probable } \\
\text { mediator of RNA } \\
\text { polymerase II } \\
\text { transcription subunit 37c } \\
\text { [Oryza sativa.L Japonica } \\
\text { Group] }\end{array}$ & XP_015618966.1 & $5.10 / 71.32$ & 41 & 28 & 4 & down \\
\hline & Folding & 179 & $\begin{array}{l}\text { PREDICTED: stromal } 70 \\
\text { kDa heat shock-related } \\
\text { protein (Hsp70) [Oryza } \\
\text { sativa.L Japonica Group] }\end{array}$ & XP_015639965.1 & $5.12 / 73.68$ & 105 & 40 & 5 & down \\
\hline & & 183 & $\begin{array}{l}\text { PREDICTED: heat shock } \\
\text { cognate } 70 \text { kDa protein } 2 \\
\text { (Hsp70) [Oryza sativa.L } \\
\text { Japonica Group] }\end{array}$ & XP_015630538.1 & $5.10 / 71.46$ & 69 & 39 & 6 & up \\
\hline $\begin{array}{l}\text { Signal } \\
\text { transduction }\end{array}$ & & 50 & $\begin{array}{l}\text { PREDICTED: guanine } \\
\text { nucleotide-binding protein } \\
\text { subunit beta-like protein A } \\
\text { [Oryza sativa.L Japonica } \\
\text { Group] }\end{array}$ & XP_015620921.1 & $5.95 / 36.67$ & 56 & 36 & 10 & up \\
\hline \multirow[t]{3}{*}{ Diease/defence } & $\begin{array}{l}\text { Stress } \\
\text { response }\end{array}$ & 24 & $\begin{array}{l}\text { PREDICTED: L-ascorbate } \\
\text { peroxidase 2, cytosolic } \\
\text { [Oryza sativa.L Japonica } \\
\text { Group] }\end{array}$ & XP_015646556.1 & $5.21 / 27.22$ & 106 & 39 & 15 & down \\
\hline & & 34 & $\begin{array}{l}\text { PREDICTED: thioredoxin- } \\
\text { like protein CDSP32, } \\
\text { chloroplastic [Oryza } \\
\text { sativa Japonica Group] }\end{array}$ & XP_015646731.1 & $6.27 / 32.48$ & 46 & 26 & 8 & down \\
\hline & & 61 & $\begin{array}{l}\text { hypothetical protein } \\
\text { Osl_29063 [Oryza sativa } \\
\text { Indica Group] }\end{array}$ & EAZ06824.1 & $5.88 / 31.98$ & 96 & 41 & 13 & down \\
\hline \multirow[t]{2}{*}{ Unkown } & & 23 & $\begin{array}{l}\text { PREDICTED: thylakoid } \\
\text { lumenal } 29 \text { kDa protein, } \\
\text { chloroplastic [Oryza } \\
\text { sativa.L Japonica Group] }\end{array}$ & XP_015636056.1 & $8.67 / 38.44$ & 109 & 56 & 15 & up \\
\hline & & 29 & $\begin{array}{l}\text { PREDICTED: } \\
\text { uncharacterized protein }\end{array}$ & XP_015632967.1 & $6.34 / 27.95$ & 66 & 24 & 9 & up \\
\hline
\end{tabular}


BAD16990.1

EEC73516.1 Indica Group]

a: Protein spot IDs as denoted in Figure 5. b: Protein identification (protein ID [reference organism], accession no. and matched peptide sequences) was determined by database searches using the MASCOT software (www.matrixscience.com) in the NCBInr, Swiss Prot and EST databases. C: Accession No.: accession number. d: Pi/Mr: theoretical Mr/pl, molecular weight (Mr, expressed in Kilodalton) and isoelectric point (pl) of the identified proteins. e: Mo: MOWSE score. f: PM: number of peptides matched. g: SC: percentage of sequence coverage (\%).

\section{Figures}

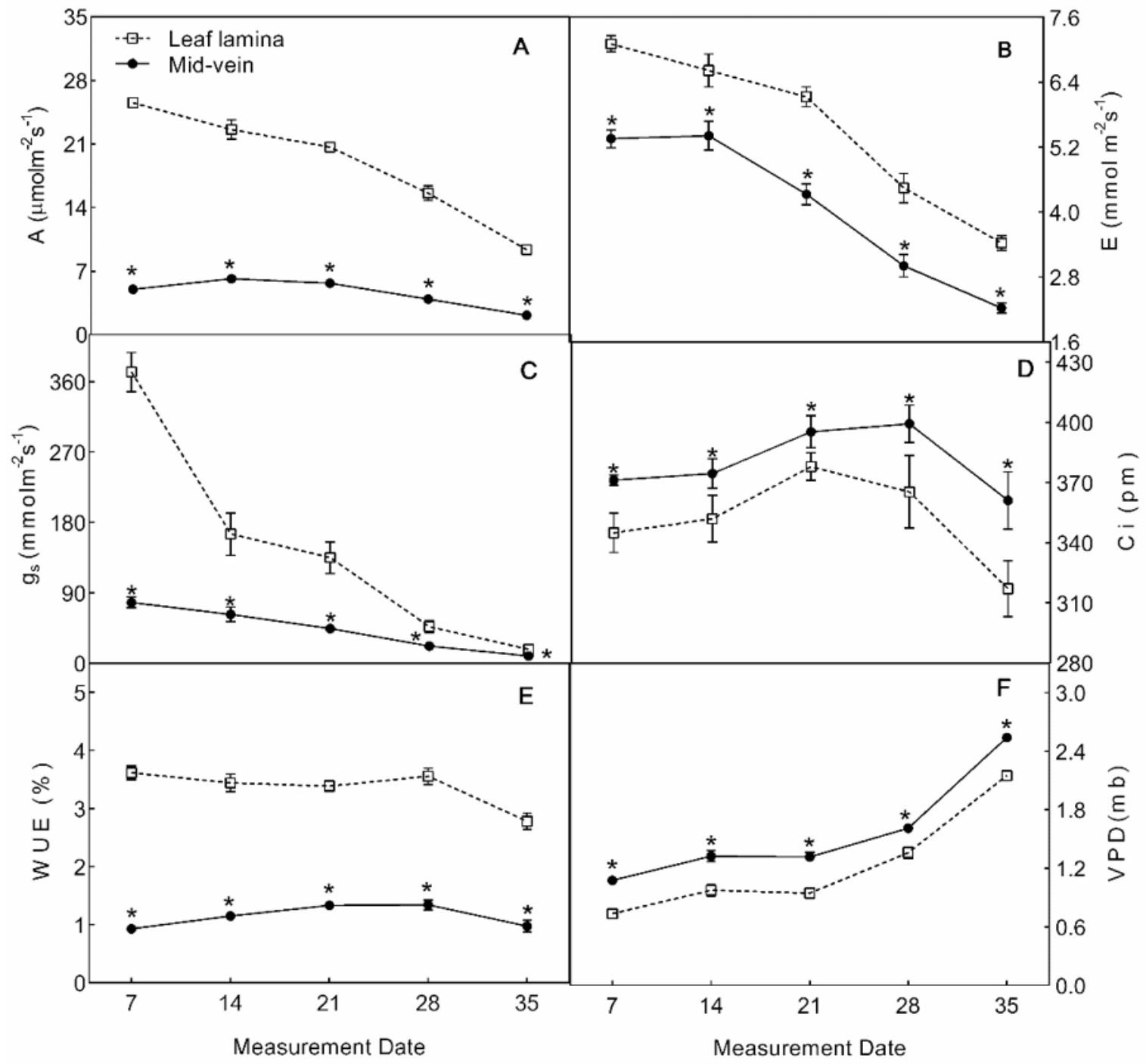

Figure 1

Changes of photosynthetic parameters in the leaf lamina and mid-vein during senescence. (A) Assimilation rate (A). (B) Transpiration rate (E). (C) Stomatal conductance (gs). (D) Internal CO2 concentration (Ci). (E) Water use efficiency (WUE). (F) Vapor pressure deficit (VPD). Open symbols ( $\square$ ) indicate lamina, solid symbols $(\mathbf{O})$ indicate mid-vein. *indicate significant differences at $P<0.05$ between the leaf lamina and mid-vein. Data are means with error bars indicating SD $(n=10)$. 


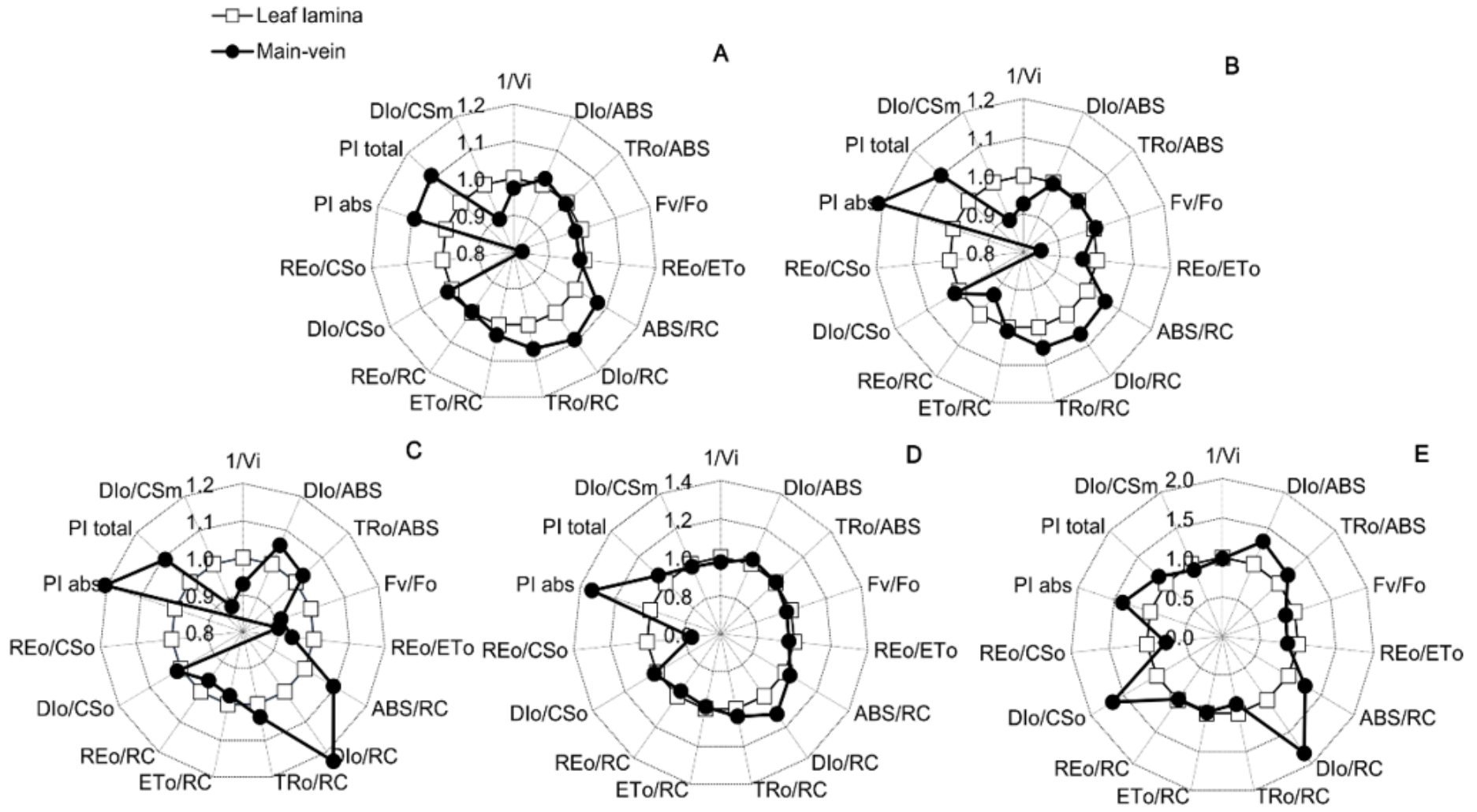

Figure 2

Spider plot of variation in selected fluorescence transient parameters between the mid-vein and leaf lamina. Open symbols ( $\square$ ) indicate lamina, solid symbols ( $)$ indicate mid-vein. *indicate significant differences at $\mathrm{P}<0.05$ between the leaf lamina and mid-vein. Data are means with error bars indicating SD $(n=10)$. 


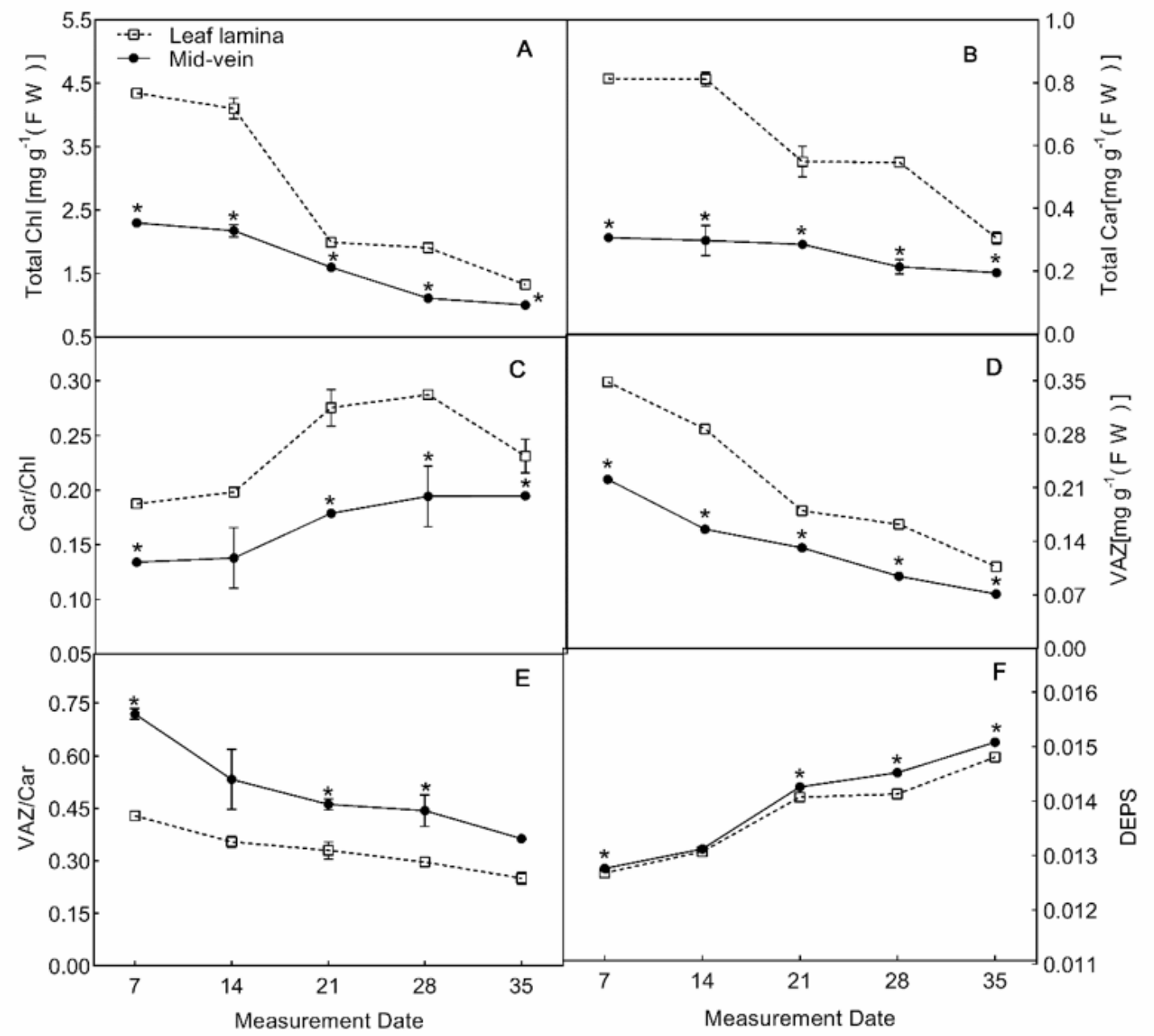

\section{Figure 3}

Fresh weight-based total chlorophyll carotenoid content and De-epoxidation state (DEPS) in the lamina and mid-vein during senescence. VAZ = violaxanthin + antheraxanthin + zeaxanthin $(V+A+Z), D E P S=(Z+0.5 A) / V A Z$. Open symbols $(\square)$ indicate lamina, solid symbols $(\mathbf{O})$ indicate midvein. *indicate significant differences at $P<0.05$ between the leaf lamina and mid-vein. Data are means with error bars indicating $S D(n=3)$. 


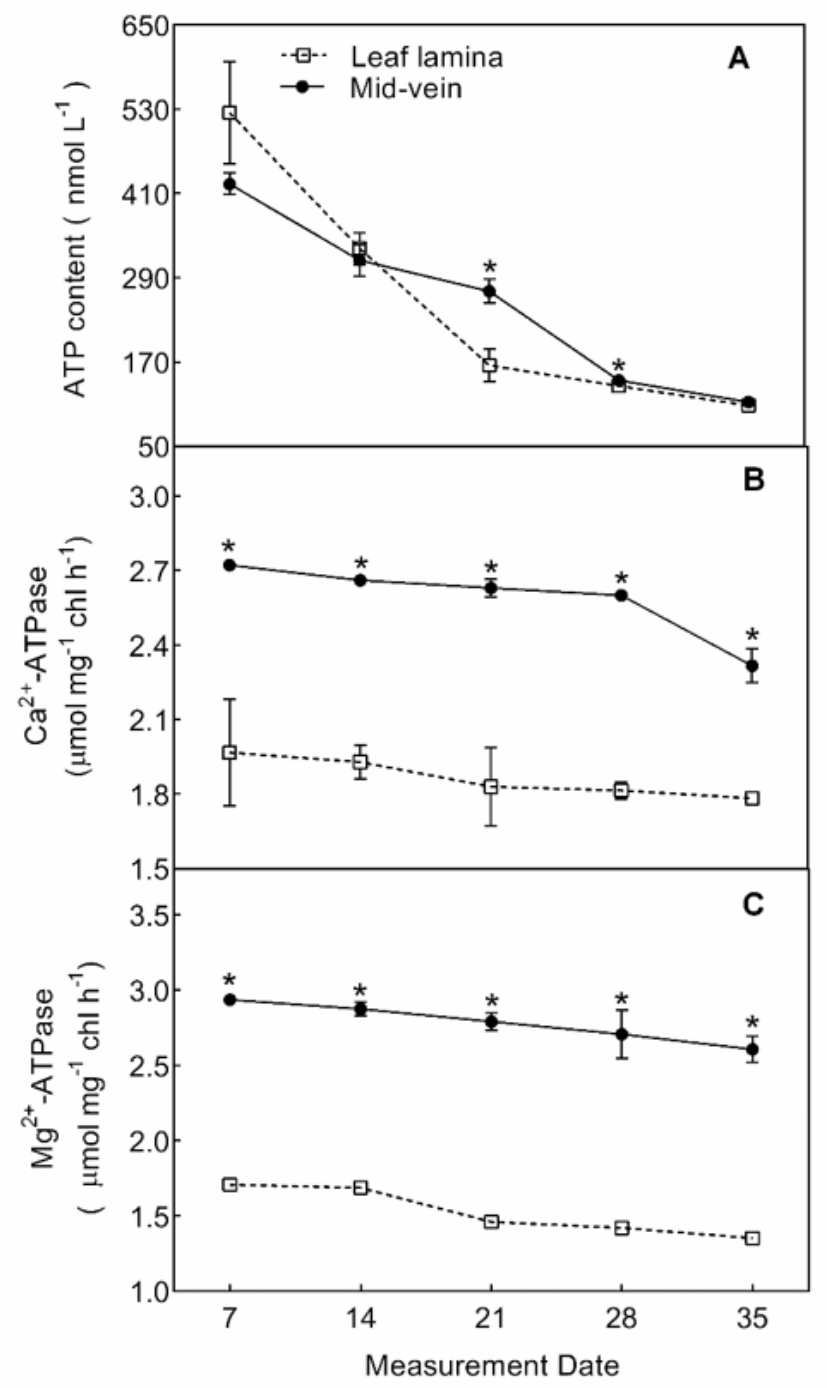

\section{Figure 4}

ATP content, Ca2+-ATPase and Mg2+-ATPase activities in the leaf lamina and mid-vein during senescence. Open symbols ( $\square$ ) indicate lamina, solid symbols ( $)$ indicate mid-vein. *indicate significant differences at $\mathrm{P}<0.05$ between the leaf lamina and mid-vein. Data are means with error bars indicating SD $(n=3)$. 


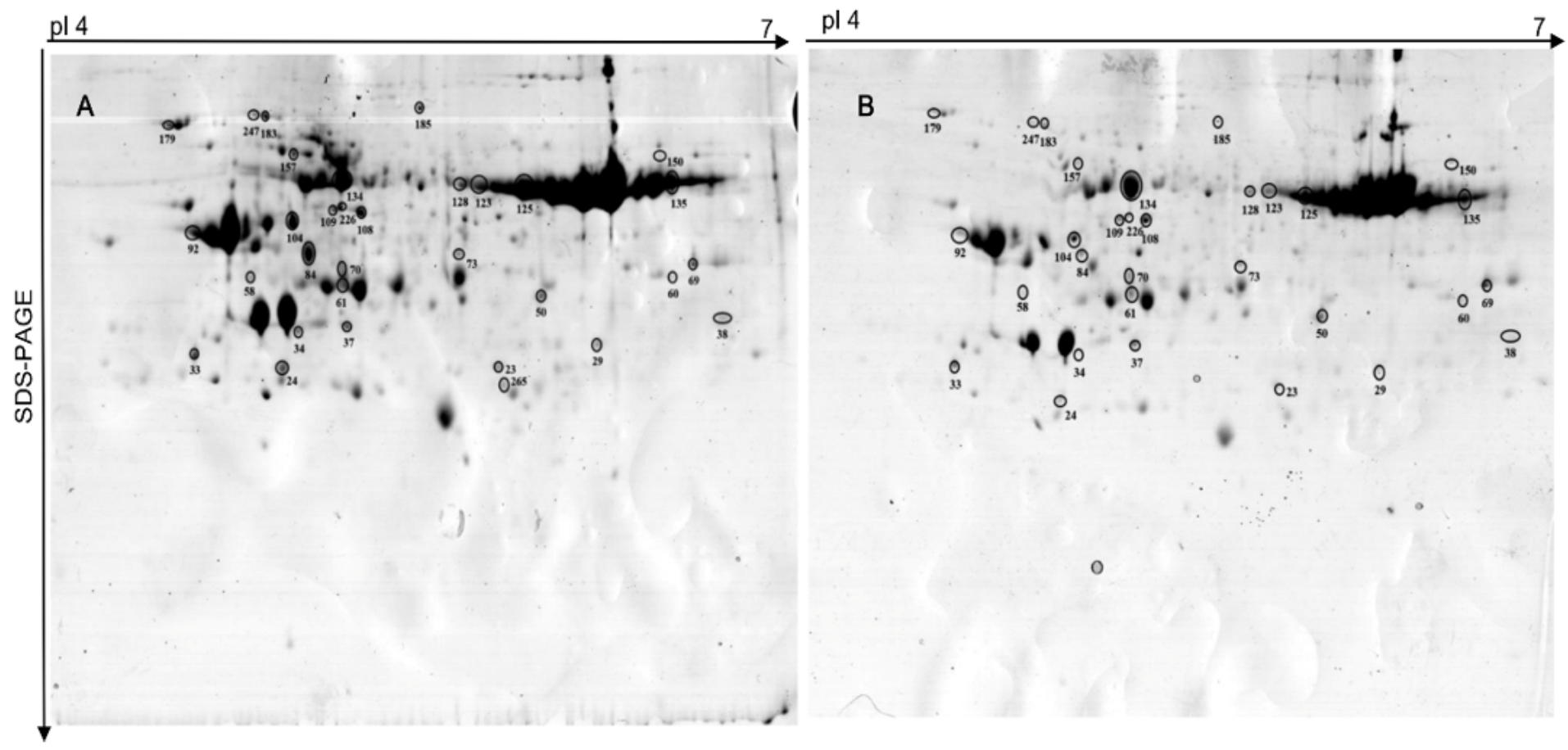

Figure 5

Two-dimensional electrophoresis (2-DE) PAGE gel image of proteins extracted from the lamina (A) and mid-vein (B) during senescence. The spots were visualized by CBB-R250 staining. Differentially present protein spots are numbered and indicated by circles. 
A

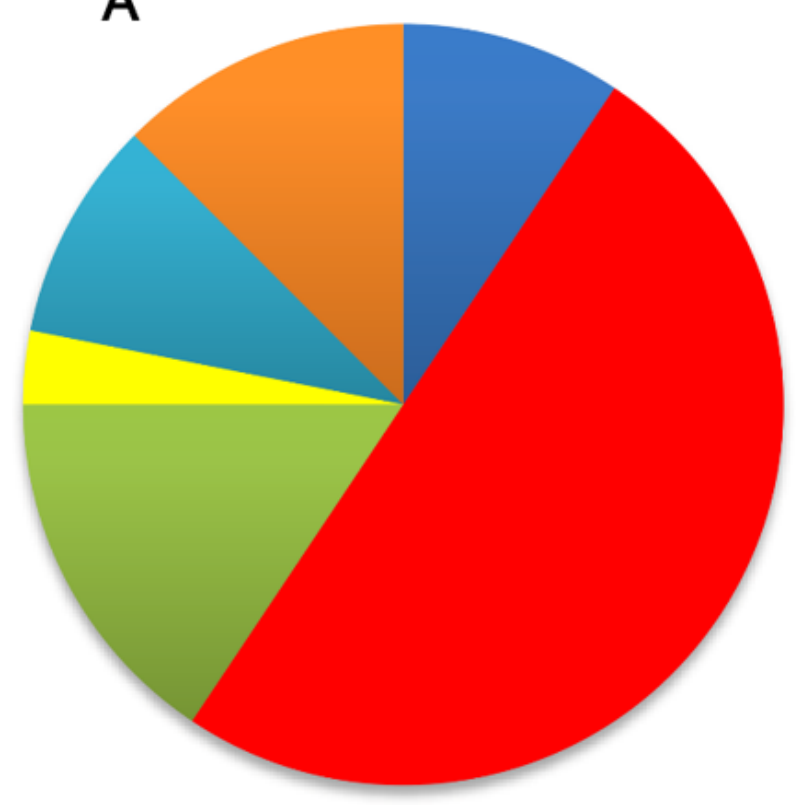

- Metabolism, $9.375 \%$

- Energy, $50 \%$

- Protein sythesis and stroage, $15.625 \%$

Signal transduction, 3.125\%

— Diease/defence, $9.375 \%$

- Unkown, $12.5 \%$
B

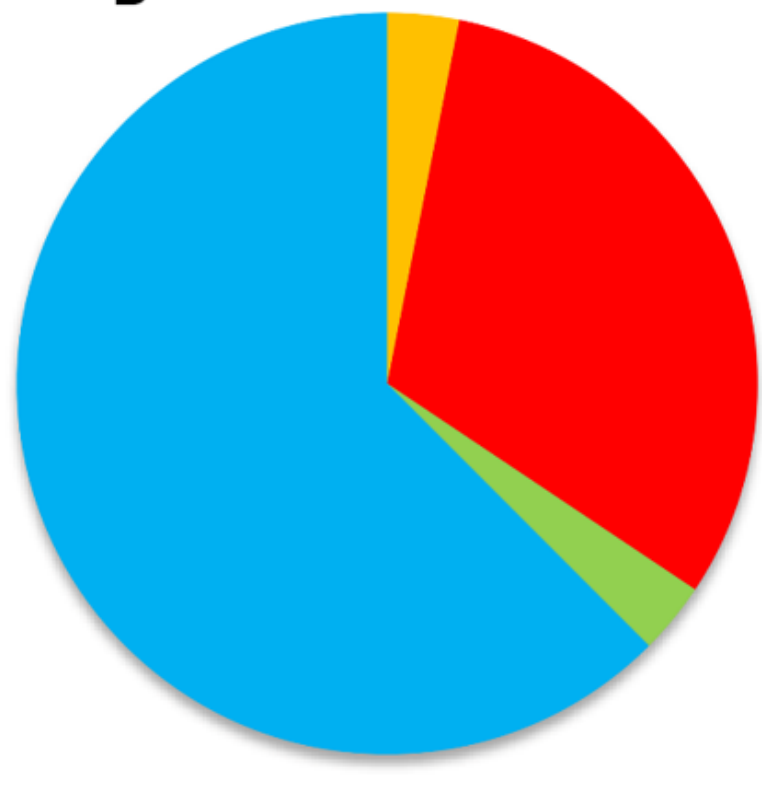

nucleus, $3.125 \%$

cytoplasm, $31.25 \%$

mitochondria, 3.125\%

a chloroplast, $62.5 \%$

\section{Figure 6}

Functional classification (A) and subcellular localization (B) of identified differentially present proteins. 


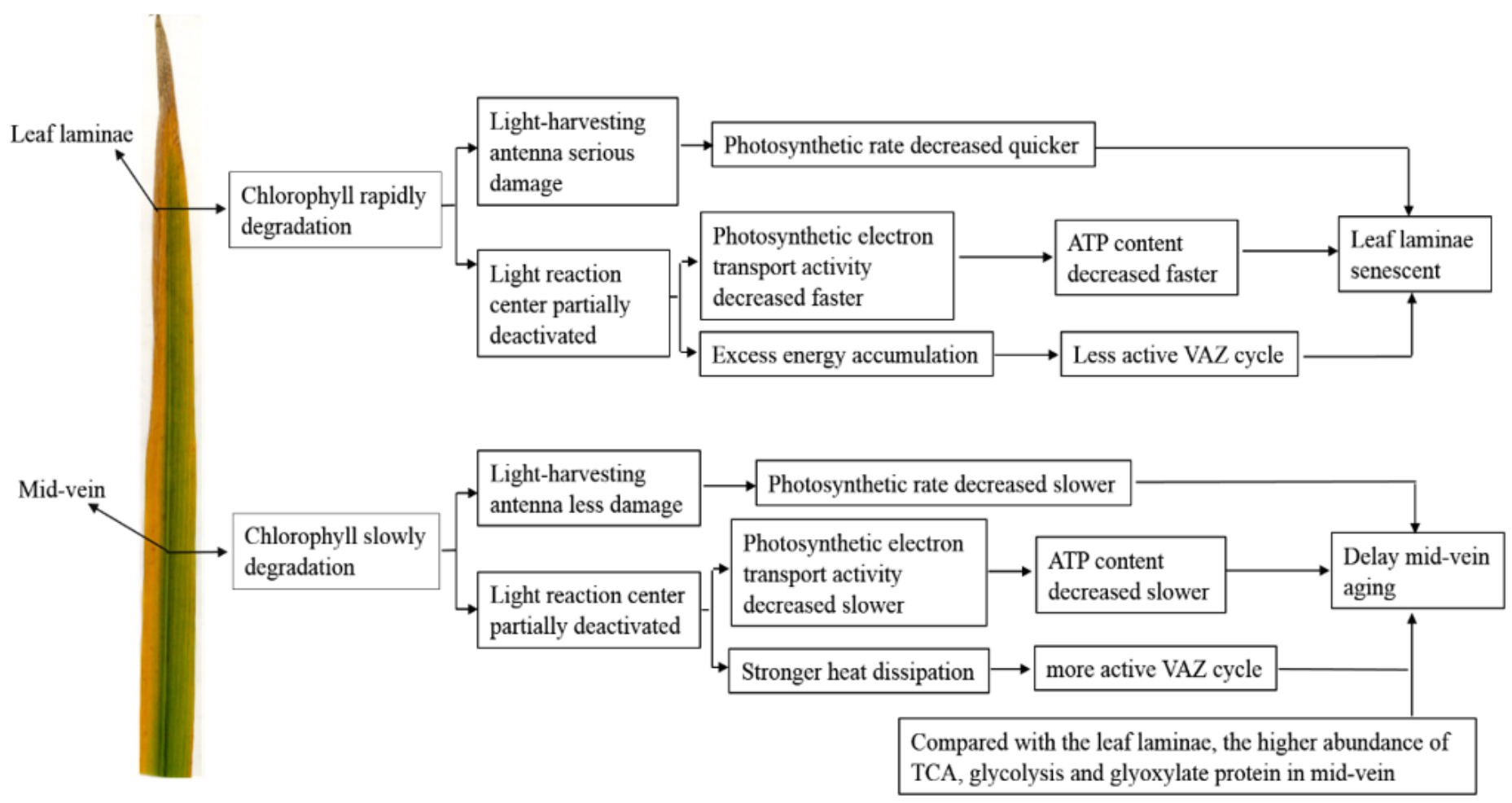

Figure 7

Summary of differences between the leaf lamina and mid-vein during senescence 